\title{
Nurses' Knowledge, Practice, Attitude and Psychological Stressors Regarding COVID-19 at Quarantine Hospital
}

\author{
Mohamed Goda Elbqry ${ }^{1, *}$, Bassam Mansour², Abeer Ezzat Elsayed ${ }^{3}$, Maged Bahi Eldin \\ Mohamed $^{4}$, Haydy Hassan Sayed ${ }^{5}$, Ashraf Tantwy ${ }^{6}$, Fatma Mohamed Elmansy ${ }^{7}$
}

Medical Surgical Nursing, Faculty of Nursing Suez Canal University, Ismailia, Egypt ${ }^{1,7}$

Infectious and Endemic Diseases, Faculty of Medicine Suez Canal University, Ismailia, Egypt ${ }^{2}$

Medical Microbiology and Immunology, Faculty of Medicine Suez Canal University, Ismailia, Egypt $^{3}$, President of Medical Psychiatric departments, Medical Academic Armed Force, Cairo, Egypt $^{4,}$ Psychiatric and Neurology, Faculty of Medicine Suez Canal University, Ismailia, Egypt ${ }^{5,6}$

\begin{abstract}
Background: Once Corona virus disease 2019 discovered in December 2019 at Wuhan, China, is considered an emerging respiratory disease developed by a novel coronavirus. Effect on 10\%$20 \%$ of total healthcare workers, mainly were nurses due to direct contact with the cases. Aim: The aim of this study was to assess nurses' knowledge, practice, attitude, and psychological stressors regarding COVID-19 at quarantine hospital. Methods: A descriptive cross-sectional research design was used. Subjects: A Convenient sample of 183 nurses participated in this study. Tools: Utilize the study with two online tools; Tool I, self-administrated questionnaire to assess level of knowledge, practice, and attitude. Tool II, COVID-19 psychological stressors questionnaire to assess the varied COVID-19 stressors among the studied nurses. Results: The findings revealed that the studied nurses had a satisfactory level of knowledge and practice. Majority of them had positive attitude (98\%) and null stressors (48\%) toward COVID-19. In addition, there is a significant correlation between nurses' knowledge level and COVID-19 psychological stressors. Conclusion: The study concluded that the studied nurses were satisfied and had a positive attitude with null stressors regarding COVID-19. Recommendations: Continuous updating nurses' knowledge and practice. Ensure all facilities to promote their attitude, psychological support to battle the present pandemic.
\end{abstract}

Key Words: Attitude, COVID-19, Nurses' Knowledge, Practice, Psychological Stressors, Quarantine Hospital. 


\section{INTRODUCTION}

Corona virus disease 2019 is an emerging respiratory disease that developed by a novel Corona virus and primarily detected in December 2019 at Wuhan, China, announced by World Health Organization (WHO) that novel corona virus in February 2020 was titled as Severe Acute Respiratory Syndrome Corona Virus 2 (SARS-CoV-2) (World Health Organization. 2020). The pandemic is marked as an infectious condition, and globally healthcare systems have become overwhelmed and be a vulnerable; its cardinal clinical symptoms includes non-productive cough, fever, myalgia, fatigue, and dyspnea; that's required special attentions and emergent considerations (Chen, et al., 2020; National Health Commission of China, 2020).

Unprecedented incidence rate of infection and death even in developed countries, it means that the current widespread pandemic has been partly concerned with a delayed investigation and poor or incomplete performance and awareness (World Health Organization. 2020). About transmission within hospitals and protection of healthcare workers are important efforts in the epidemic condition, the understanding or/and acquiring enough knowledge regarding sources, clinical pictures, modes of transmission, and prevention measure among nurses can play a crucial roles for this assessment to prevent susceptible infection and maintain integrity of healthcare system (Zhou, et al. 2020).

Nurses are highly risk group and more vulnerable to COVID-19 infection, as whole healthcare workers counts $10-20 \%$ of total cases mostly are nurses. Nurses' knowledge of COVID-19 prevention and protection procedures can help prevent the transmission chain (Al-Hanawi, et al., 2020). The outbreak is a major challenging in humanitarian and low-income country contexts due to gradual growing of the pandemic not only in Egypt and there is no enough knowledge with/ or poor practice regarding the awareness and attitude among nurses staff regarding this infectious disease in additional to burden of psychological stressors and Moreover, more incidents have recognized, such as suicide attempts of nurses caring for critically ill patients, in Korea, Italy and China (The Novel Coronavirus Pneumonia Emergency Response Epidemiology Team. 2020). 


\section{Significant of the study:}

Unfortunately, SCU quarantine hospital recorded 7 nurses' cases in the 1st week of opening (Suez Canal University News. 2020). The same concern; dramatic increase cases and death rate among nurses not only in Egypt has led to unprecedented psychological stressors, impose a significant level of anxiety and stress, leads to disturbance level of knowledge, practice and attitude and burn out. For these concerns we have investigated nurses towards the present emerging health crisis.

\section{Aim of the Study}

The aim of this study was to assess nurses' knowledge, practice, attitude, and psychological stressors regarding COVID-19 at quarantine hospital.

\section{Research questions}

1- What is the level of the studied nurses' knowledge, practice, attitude, and psychological stressors toward COVID-19?

2- Is there a correlation between the studied nurses' level of knowledge, practice, and attitude with psychological stressors toward COVID-19?

\section{Subject and Method}

Design: A descriptive cross-sectional research design was used in the study.

Setting: This study was conducted at quarantine hospital in Suez Canal University hospitals (was opened by president of university at 18/6/2020, consists of 4 levels involved 14 ICU bed, 114 inpatients bed, operations room, hemodialysis, laboratory unit and housing rooms for Healthcare workers).

Subject: A convenient sample of nurses was participated to conduct aim of the study, which are available and accepted at the time of data collection. Actually, involved 183 nurses were completed and recruited in the study from June to August 2020.

\section{Tools for data collection}

Tools were utilized to collect data for the current study, as the following: 
Tool (I): Self Administrated Questionnaire: It adapted by the researchers based on related review of literature and other concerned studies, shared online through registered contact's way to the studied nurses (Al-Hanawi, et al., 2020; National Health commission of Chin, 2020; World Health Organization, 2020; Zhou, et al., 2020). It consisted of the following 4 parts:

Part 1: It used to assess the studied nurses' demographic characteristics, such as: Age, gender, degree of education, years of experience, marital status, and place of residence.

Part 2: It consisted of 15 items, used to assess the studied nurses' knowledge regarding COVID19 (definition, risk factors, and modes of transmission, clinical manifestations, prevention, and management) (Al-Hanawi, et al., 2020; National Health commission of Chin, 2020).

Scoring system: The total score of knowledge was ranged from 0-15 grades, each correct answer was given one grade, and $\geq 60 \%$ was considered a satisfied knowledge; considered this value due to most of the studied nurses had diploma and technical institute degree.

Part 3: It consisted of 20 items, used to assess the studied nurses' practice regarding COVID-19 preventive and infection control measures (wearing and removing personal protective equipment, isolation measures, hand washing, cleaning and disinfection of surfaces, wastes management) (World Health Organization, 2020; Zhou, et al., 2020).

Scoring system: The total score of knowledge was ranged from 0-20 grades, each correct answer was given one grade, and $\geq 60 \%$ was considered a satisfied level of practice; considered this value due to most of the studied nurses had diploma and technical institute degree.

Part 4: It used to assess the studied nurses' attitude toward COVID-19, consists of 6 questions (Al-Hanawi, et al., 2020; Zhou, et al., 2020).

Scoring system: The level of agreement on 3 points Likert scale; with 3= "agree", $2=$ "neutral", $1=$ "disagree", and $\geq 60 \%$ was considered a positive attitude; considered this value due to most of the studied nurses had diploma and technical institute degree.

Tool (II): COVID-19 Psychological Stressors Questionnaire: shared online through registered contact's way; adapted by the researcher and translated into simplified valid Arabic language. 
A stable 5-factor solution was identified developed by (Taylor, et al. 2020). It used to assess COVID-related stress and anxiety symptoms: (1) Danger and contamination fears, (2) fears about economic consequences, (3) xenophobia (4) compulsive checking and reassurance seeking and (5) traumatic stress symptoms about COVID-19.

Scoring system: Total scores were ranged from 0 to 90 degree, while (0) means null, (1) means Mild, (2) mean moderate, (3) severe. Totally, zero score means to be null, 1-30 means mild, 3160 means moderate, while over 60 are likely to have a severe level of stressors.

Content Validity: Tools of data collection was be tested for validity by a panel of five experts in the related field to determine whether the included items are understandable, clear, suitable, applicable, and comprehensive to achieve the aim of the study.

Content reliability: Coefficient of reliability of the evaluating tools I and II was measured by Cronbach's $\alpha$ alpha, the reliability scores were $(0.81)$ and $(0.79)$ which indicate high internal consistency of the used tools.

A pilot study: A pilot study was be carried out on $10 \%$ of the studied nurses (18) to test clarity, feasibility, applicability, and to estimate the needed time to complete each tool. Necessary modifications were done, and pilots' nurses were excluded.

\section{Field Work}

- The study started and completed within planned time "Five months". All administrative requirements were obtained before starting data collection:

- An official letter for legibility of the study was obtained from the ethics committee, Faculty of Nursing "code No. 81, dated 29/6/2020".

- Oral assent from the president of Suez Canal University (SCU) and informed consent from director of SCU hospitals to start questionnaire sharing and data collection.

- Online informed consent from the studied nurses was obtained to recruit and complete the study.

- Contact's ways were obtained from the studied nurses who agreed to participate in the study after explaining the aim of the study and confirm anonymity. Data collections were distributed in various sessions among participants based on their rooster time away from their 
busy time. The researchers' contacts were being available for any interpretations post sharing online questionnaires' link.

- Data were collected using a valid and registered the studied nurses' contact (E-mail contact, Mobile' contact) to share online questionnaires' links in the Google drive form.

\section{Ethical considerations:}

All the studied nurses were informed about the aims of the study; assured of maintaining anonymity, confidentiality of collected data and the right to withdraw from the study at any time. Participants in the survey are voluntaries neither rewarded nor plenty.

\section{Statistical design:}

The raw data coded and entered SPSS system files (Version 20), conducted using the following statistical measures: including frequency; distribution, mean, and standard deviation to describe different characteristics. The chi-square $\left(\mathrm{X}^{2}\right)$ is nonparametric test; used to evaluate a correlation between two variables, while significant $\mathrm{P} \leq 0.05$.

\section{Limitation of the study:}

Ongoing rising of pandemic condition interferes with other participants to involve in the study. Nature of pandemic situation gets out the researcher from direct observation of other nurses' practice.

\section{RESULTS:}

Table 1: showed that more than one third (48\%) of the studied nurses aged $20:<29$ and more than half $(61 \%)$ were female. About educational degree less than half $(45 \%)$ had technical institute, more than three quarter $(56 \%)$ of the studied nurses had 6-10 years of experience. While more than half (53\%) were married and more than two third had (69\%) urban residence

Table 2: clarified that more than three quarter of the studied nurses had satisfactory level of knowledge (95.1\%) and practice (88.5\%) regarding COVID-19.

Figure 1: illustrated that approximately all $(98.4 \%)$ the studied nurses had positive attitude, while $(1.6 \%)$ had negative attitude toward COVID-19 
Figure 2: declared that more than one third (48.9\%) of the studied nurses had null level of COVID-19 psychological stressors, while less than one quarter (1.6\%) had severe psychological stressors level.

Table 3: presented that there was a significant correlation between knowledge level and COVID-19 psychological stressors level with $\mathrm{P}$ value was a significant $\leq 0.01$.

Table (1): Frequency and distribution of demographic characteristics of the studied nurses $(n=183)$.

\begin{tabular}{|c|c|c|}
\hline Variables & No & $\%$ \\
\hline \multicolumn{3}{|l|}{ Age } \\
\hline - $20:<29$ & 88 & $48 \%$ \\
\hline - $29:<39$ & 69 & $38 \%$ \\
\hline - $\geq 39$ & 26 & $14 \%$ \\
\hline \multicolumn{3}{|c|}{$\mathrm{M} \pm \mathrm{SD}=29 \pm 9$} \\
\hline \multicolumn{3}{|l|}{ Sex } \\
\hline - Female & 112 & $61 \%$ \\
\hline - Male & 71 & $39 \%$ \\
\hline \multicolumn{3}{|l|}{ Educational degree } \\
\hline - Diploma & 69 & $38 \%$ \\
\hline - Technical institute & 83 & $45 \%$ \\
\hline - Bachelor & 31 & $17 \%$ \\
\hline \multicolumn{3}{|l|}{ Experience } \\
\hline - $1-5$ & 81 & $44 \%$ \\
\hline - $6-10$ & 102 & $56 \%$ \\
\hline \multicolumn{3}{|l|}{ Marital status } \\
\hline - Single & 79 & $43 \%$ \\
\hline - $\quad$ Married & 97 & $53 \%$ \\
\hline - Divorced & 6 & $3.5 \%$ \\
\hline - Widowed & 1 & $0.5 \%$ \\
\hline \multicolumn{3}{|l|}{ Residence } \\
\hline - Urban & 127 & $69 \%$ \\
\hline - Rural & 56 & $31 \%$ \\
\hline
\end{tabular}


Table (2): Satisfactory level of knowledge and practice score of studied nurses regarding COVID-19 $(n=183)$.

\begin{tabular}{|l|c|c|c|}
\hline \multirow{2}{*}{ Variables } & \multicolumn{2}{|c|}{ Satisfactory score } & \multirow{2}{*}{ M } \\
\cline { 2 - 3 } & $\mathrm{N}$ & $\%$ & \\
\hline Total knowledge Score & 174 & 95.1 & $11.28 \pm 1.57$ \\
\hline Total practice Score & 162 & 88.5 & $13.81 \pm 2.05$ \\
\hline
\end{tabular}

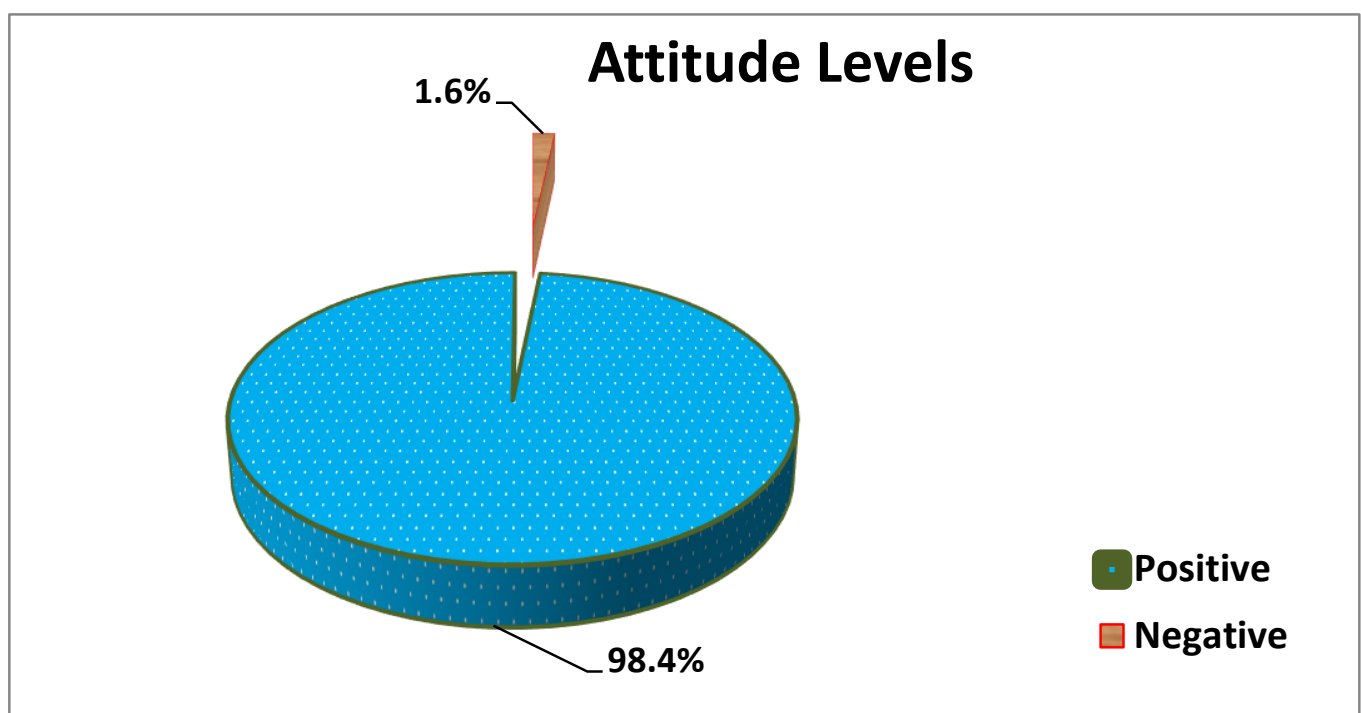

Figure (1): Attitude levels of studied nurses toward COVID-19 (n=183).

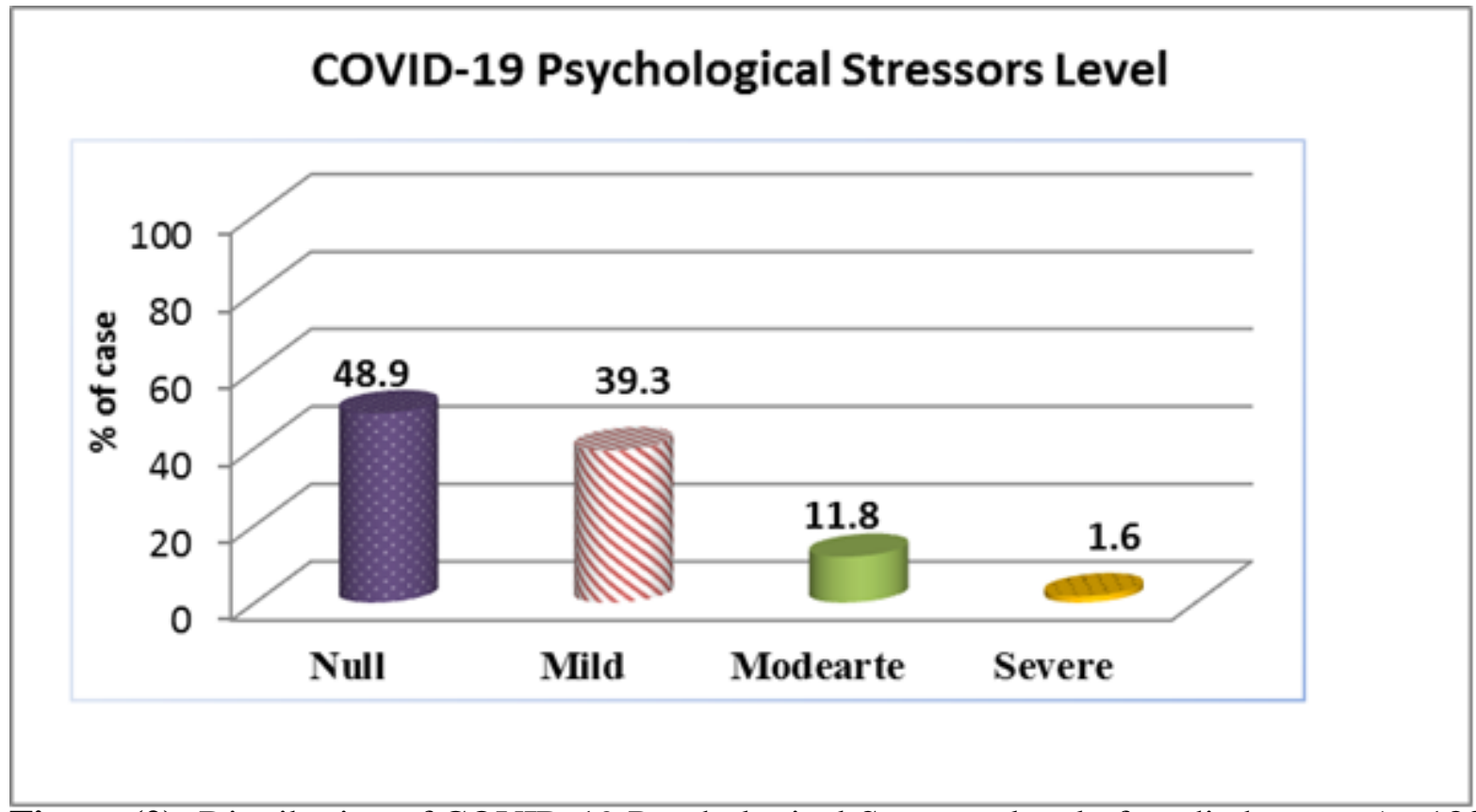

Figure (2): Distribution of COVID-19 Psychological Stressors level of studied nurses ( $\mathrm{n}=183)$. 
Table (3): Correlation between total level of knowledge, practice, attitude, and COVID-19 Psychological Stressors

\begin{tabular}{|c|c|c|c|c|c|c|c|c|c|c|}
\hline \multirow{3}{*}{ Variables } & \multicolumn{8}{|c|}{ COVID-19 Psychological Stressors level } & \multirow{3}{*}{$\chi^{2}$} & \multirow{3}{*}{$P$ valu } \\
\hline & \multicolumn{2}{|c|}{ Null } & \multicolumn{2}{|c|}{ Mild } & \multicolumn{2}{|c|}{ Moderate } & \multicolumn{2}{|c|}{ Severe } & & \\
\hline & $\mathbf{N}$ & $\%$ & $\mathbf{N}$ & $\%$ & $\mathbf{N}$ & $\%$ & $\mathbf{N}$ & $\%$ & & \\
\hline \multicolumn{11}{|l|}{ Knowledge Level } \\
\hline Satisfactory & 86 & 100 & 56 & 2.86 & 29 & 100 & 3 & 100 & \multirow[b]{2}{*}{18.17} & \multirow{2}{*}{$.001 *$} \\
\hline Un satisfactory & 0 & 0 & 9 & 13.8 & 0 & 0 & 0 & 0 & & \\
\hline \multicolumn{11}{|l|}{ Practice Level } \\
\hline Satisfactory & 73 & 9.84 & 62 & 4.65 & 24 & 8.82 & 3 & 100 & \multirow[b]{2}{*}{47.5} & \multirow[b]{2}{*}{.140} \\
\hline Un satisfactory & 13 & 15.1 & 3 & 4.6 & 5 & 17.2 & 0 & 0 & & \\
\hline \multicolumn{11}{|l|}{\begin{tabular}{|l} 
Attitude level \\
\end{tabular}} \\
\hline Positive & 86 & 100 & 62 & 4.95 & 29 & 100 & 3 & 100 & \multirow[b]{2}{*}{53.5} & \multirow[b]{2}{*}{.136} \\
\hline Negative & 0 & 0 & 3 & 4.6 & 0 & 0 & 0 & 0 & & \\
\hline
\end{tabular}

$x^{2}$ is chi-square test; $P$ value is significant $\leq 0.05$

\section{DISCUSSION:}

Nurses are the main core of multidisciplinary treatment plan because they are responsible for provide direct care to the patients and spent more time in the hospital, being more vulnerable to COVID-19 pandemic transmission, the pandemic is ongoing and actively and countries even developing around the world are taking drastic policies to suppress the spread of infection by measures like social distancing, wearing mask, closing of academics and nonessential work (Kamineni, et al. 2020).

This study was implemented in the emergency time at the peak of COVID-19 at the worldwide and in Egypt. The current findings of the study discussed in four main concerns that.

First part; demographic data. The studied nurses revealed that less than half aged $20<$ 
29 , more than two third of them were experienced $5<10$ years and graduated from diploma and technical institute of nursing, as well as more than one third of them were female. The researchers point of view possibly; due to highly females' admission to nursing institutions and diploma in Ismailia government or related to recent recruitment of them, while more than half are married and were had urban residence; may be related to culture and family attitude to early marriage.

This is agreed with (Al-Hanawi, et al., 2020). They found that more than two third of studied nurses were female and aged more than 20 years and possibly all the studied nurses were had more than 5 years of experience. Disagreed with (Nemati, Ebrahimi \& Nemati, 2020). They found more than half of the studied nurses were male and more than two third were had master's degree.

Second part; Level of Knowledge, Practice, and Attitude. More than three quarter of the studied nurses were had satisfied level of knowledge regarding COVID-19. The researchers point of view; may be related to they had a lot of experience, massive national and international educational intervention and training regarding COVID-19 pandemic situation in certified platform as well as continuous hospital updating policies and procedure regarding to COVID-19 preventive measures relied on WHO guidelines and concerned healthcare organizations. However, a significant group still depended on social media, television, and even friends and family to get information. This is on line with (Saadeh, Sacre, Hallit, Farah, Salameh, 2020). They found that approximately of the studied nurses were had good level of knowledge regarding this pandemic condition, possibly related to more them were highly educated and availability of certified informational source regarding this pandemic.

On behalf; more than two third of the studied nurses were had satisfied level of practice regarding COVID-19, may be related to consecutive and closely checking what are updates regarding to COVID-19 prevention and control measures as well as self-learning to avoid catching infection with availability of E-learning platforms. This is agreed with (Zhou, et al., 2020). They found mostly of the studied nurses were had satisfied level of practice toward COVID-19 policies and procedures, possibly from the researcher point of view; related to highly educational level, hospital promotion of staff practice through frequent training programs and 
internal motives to avoid catching infection .

Furthermore, regarding to attitude of the studied nurses with COVID-19, revealed that more than three quarter were had positive attitude. This possibly from the researcher point of view; related to sufficient level of knowledge, practice level and trusted national and international governmental role to control this pandemic situation such as availability of facilities and continuous evaluation their needs. Compatible with (Alwani, et al. 2020). They found that more than half of the studied nurse had good attitude toward this pandemic condition with satisfied level of knowledge. This result is not on line with (Saadeh, Sacre, Hallit, Farah, Salameh, 2020). Found that more than half of the studied nurses were very afraid and less adequate COVID-19 infection.

Third part; Concerned with COVID-19 psychological stressors. Fortunately; based on findings of the study more than one third of the studied nurses were had null psychological stressors, while less than one quarter were had severe psychological stressors, probably from the researchers point of view; because of closely rigorous infection control measures, positive attitude, being trusted toward effective governmental role to prevent spread infection and proper self-esteem. Compound with (Nemati, Ebrahimi \& Nemati, 2020). They found that mostly of nurses had less psychological stressors toward COVID-19, with good attitude, while is contradicted with (Al-Hanawi, et al. 2020). They found that more than three quarter of the studied nurses were had severe psychological stressor regarding overgrowing of the pandemic.

Fourth part; Correlation. Behalf of the finding; There is a positive correlation between COVID-19 psychological stressors and nurses' level of knowledge regarding COVID-19, while there is no significant correlation with the studied nurses level of practice and attitude to the pandemic situation, occasionally may be concerned with low stressors on the studied nurses, proper practice. This is accepted with (Al-Hanawi, et al. 2020; Nemati, Ebrahimi \& Nemati, 2020; Zhou, et al. 2020). They found that there is satisfied level of the studied nurses' knowledge and correlated with their total COVID-19 psychological stressors score regarding 


\section{CONCLUSION :}

The current findings of the study concluded that; irrespective of varied age, gender, experience, and education nurses had satisfied knowledge, practice and positive attitude regarding COVID19 pandemic disease. Moreover, approximately less than half revealed null COVID-19 psychological stressors level, while had positive correlation between nurses' knowledge level and COVID-19 psychological stressors.

\section{RECOMMENDATION :}

Based on the findings of the study and as the global threat of COVID-19 continues to emerge, this study recommended that: continuous education and training for nurses at quarantine hospital irrespective of age, experience, or/and level of education is pivotal to battle this pandemic condition through enhancing their level of knowledge, practice, and attitude. Overcoming of Corona virus disease 2019 psychological stressors to enhance the sense of wellbeing and provide efficient nursing care. Further, studies to evaluate the effect of educational interventions with larger probability subjects regarding COVID-19 especially with the second attack.

\section{Acknowledge}

This study is recruited in an emergency time to valuable concerns, delighted to appreciate all nurses who participated in the study or withdrawal due to busy time or exhaustion and president of Suez Canal University for valuable support, also all thanks to Ethics Committee in the Faculty of Nursing for their effort and significant criticism and there urgent unscheduled meeting.

\section{Author Contributions}

- Study conception and design: ME, FE

- Data collection: ME, AT, BM

- Data analysis and interpretation: FE, AE, BM, ME

- Drafting of the article: ME, FE, AT, HH, MB

- Critical revision of the article: ME, FE, AE, AT, HH, MB, BM

Conflict of interest: Declare no conflict of interest. 
Budget source: Spent by the research team.

\section{REFERENCES :}

Al-Hanawi, M. K., Angawi, K., Alshareef, N., Qattan, A. M., Helmy, H. Z., Abudawood, Y. \& Alsharqi, O. (2020). Knowledge, Attitude and Practice toward COVID-19 among the Public in the Kingdom of Saudi Arabia: A Cross-Sectional Study. Frontiers in Public Health. 8(6), 37-39.

Alwani, S. S., Majeed, M. M., Hirwani, M. Z., Rauf, S., Saad, S. M., Shah, S. H., \& Hamirani, F. M. (2020). Evaluation of Knowledge, Practices, Attitude and Anxiety of Pakistans Nurses towards COVID-19 during the Current Outbreak in Pakistan. MedRxiv. 3(1); 1-12.

Chen N, Zhou M, Dong X, Qu J, Gong F, Han Y, Qui, P., Wang, J., Lui, Y., WEI, Y., Xia, J., Yu, T., Zhang, X., and Zhang, L. (2020).Epidemiological and clinical characteristics of 99 cases of 2019 novel coronavirus pneumonia in Wuhan, China: a descriptive study. 3(5), 507-513.

Egyptian Ministry of Health. Updates on COVID-19 (coronavirus disease 2019) local situation. Ministry of Health website, Egypt. Retrieved (10-6-2020) from http://doi. moph.gov.eg

Kamineni, S. T., Balu, P., Sivagananam, P., Chellapandian, P., Chelladurai, U. M., Jayasheelan, V. P., Bopaiah, S. K., Ravikumar, D., Myneni. S. \& Mohan, S. K. (2020). Knowledge of COVID-19 among nursing and Allied health care professionals working in tertiary care hospital. International Journal of Research in Pharmaceutical Sciences. 11(1), 103109.

National Health Commission of China (2020). Update on epidemic situation of novelcoronavirus infected-pneumonia. (Retrieved 6-7-2020 from http://doi. en.nhc.gov.cn/).

Nemati, M., Ebrahimi, B., \& Nemati, F. (2020). Assessment of Iranian nurses' knowledge and anxiety toward COVID-19 during the current outbreak in Iran. Archives of Clinical Infectious Diseases. 15(6), 56-60.

Saadeh, D., Sacre, H., Hallit, S., Farah, R., Salameh, P. (2020): Knowledge, attitudes, and practices toward the coronavirus disease 2019 (COVID-19) among nurses in Lebanon. 
Perspective in Psychiatric Care. Wiley Journal. 1(10), 1-10.

Suez Canal University's News (2020). Suez Canal University's hospital statistical record. Suez Canal University's News. (Retrieved 10-7-2020 from http://doi. suez.edu.eg./)

Taylor, S., Landry, C., Paluszek, M., Fergus, T. A., McKay, D., \& Asmundson, G. J. (2020). Development and initial validation the COVID Stress Scales. Journal of Anxiety Disorders. 8(4), 45-49.

The Novel Coronavirus Pneumonia Emergency Response Epidemiology Team (2020). The epidemiological characteristics of an outbreak of 2019 novel coronavirus diseases (COVID-19) in China. Chin J Epidemiol. 41(3), 145-51.

World Health Organization (2020). Coronavirus disease (COVID-19) pandemic. (Retrieved 30-6-2020 from https://doi. covid19.who.int/).

Zhou, M., Tang, F., Wang, Y., Nie, H., Zhang, L., You, G., \& Zhang, M.(2020).Knowledge, attitude, and practice regarding COVID-19 among Healthcare workers in Henan, China. Journal of Hospital Infection. 10(5)183-187. 
معلومات، ممارسات، سلوك التمريض و الضغوطات النفسيه تجاه جائحة كوفيد-19 بمستثفى الحجر الصحى

د. محمد جودة البقرى 1* د.بسام منصور2 أ.د/ عبيز عزت السيد33 د.ماجد بهى الدين محمد4 أ.م.د/ هايدى حسن سيد5 أ.د/ أشرف طنطاوى6 د.فاطمة محمد المنسى 7

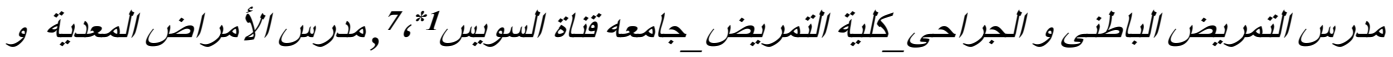

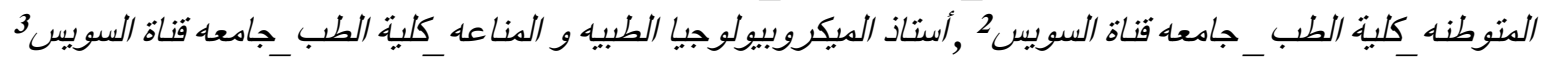

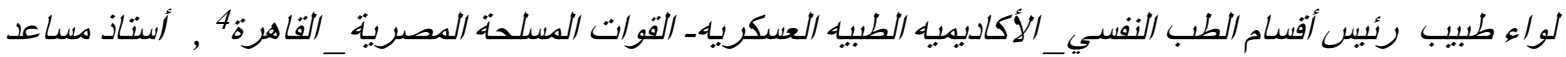

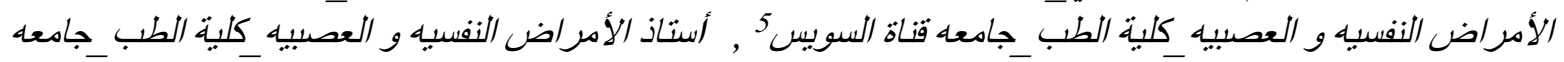
قناة السوبيس 6

\section{الخلاصة}

بمجرد اكتشاف جائحة كوفيد 2019 في ديسمبر 2019 في و هان بالصين ، أُعُنتبر مرضنًا تتفسيًا طارىه سببه فيروس كورونـا الجديد. حيث يؤثر على 10٪ -20٪ من إجمالي العاملين في مجال الرعاية الصحية وخاصة التمريض بسبب الاتصال المباشر مع الحالات. الغرض: كان الهذف من هذه الدراسة هو تقييم معلومات، ممارسات، سلوك التمريض و الضغوطات النفسية تجاه جائحة كوفيد-19 بمستشفى الحجر الصحى. تصميم البحث: تم استخدام تصميم بحث وصفي عرضسي. أخذ العينـات: شـاركت عينـة ملائمسة مـن 183 ممـرض و ممرضـه في هذه الدر اسـة. استُخدمت الدراسـة أداتين لتجميع البيانـات عبر المشـاركة الإكترونية: استبيان ذاتي لتقييم مستوى معلومات، ممارسات و سلوك التمريض تجاه جائحسة كوفيد-19، أيضـا إستبيان ذاتى لتقيم الضغوطات النفسية المختلفه للتمريض تجاه جائحة كوفيد-19. النتائج: أظهرت النتائج أن مستوى معلومـات و ممارسـات التمريض المشارلك بالدر اسه تجاه جائحة كوفيد 19 مُرضـى. كذلك أن الغالبيهه منهم ذو سلوك إيجابى (98\%) و ليس لديهم ضـوطات نفسيه (48\%) تجـاه جائحسة كوفيد-19. علاوة على ذلك هنالك علاقة بين مستوى معلومـات التمريض المشـارك بالدر اسه و الضغوطات النفسية تجاه جائحسة كوفيد-19. الخلاصـة: لخَصـت الدراسـة إلى أن معلومـات و ممارسـات التمريض المشارك بالدر اسه مُرضسى و غالبيتهم ذو سلوك إيجابى و ليس لديهم ضـوطات نفسية تجاه جائحة كوفيد-19. التوصيات: التحديث المستمر لمعلومـات وممارسـات التمريض جائحسة كوفيد 19. ضمان جميع التسـهيلات لتعزيز سـوكهم الإيجابى ، و الدعم النفسي لمحاربة الوباء الحالى.

الكلمات المرشدة : سلوك، جائحة كوفيد-19، معلومات، ممارسات التمريض، الضغوطات النفسيه و الحجر الصحى. 